\begin{abstract}
"Mircea cel Batran" Naval Academy Scientific Bulletin, Volume XX - 2017 - Issue 1
The journal is indexed in: PROQUEST / DOAJ / Crossref / EBSCOhost / INDEX COPERNICUS / DRJI / OAJI I

JOURNAL INDEX I I2OR / SCIENCE LIBRARY INDEX / Google Scholar / Academic Keys/ ROAD Open Access I Academic Resources / Scientific Indexing Services / SCIPIO / JIFACTOR
\end{abstract}

\title{
BANKRUPTCY RISK - CLASSICAL MODELS VERSUS ROMANIAN MODELS
}

\author{
Cristian Dragoș TEODORESCU ${ }^{1}$ \\ ${ }^{1} \mathrm{PhD}$. Assoc. Prof Department of Informatics, Economic Cybernetics, Finance and Accounting, \\ Faculty of Economic Sciences, Petroleum- Gas University of Ploiesti, Bulevardul București nr. 39, \\ cteodorescu@upg-ploiesti.ro
}

\begin{abstract}
In a competitive economy, business evolution is closely linked to any type of risks and their manifestations. Bankruptcy risk is due to the likelihood that a company enters into default or be declared bankrupt.

Knowing the threats related to companies, the determinant factors of risks are essential information for managers, shareholders, investors, suppliers or customers.

This paper presents classical models based on scores of forecasting bankruptcy risk (Altman, Conan \& Holder, the French model, etc.) compared to models used in the Romanian economy (Anghel, Mironiuc Robu, Cămăşoiu, etc).
\end{abstract}

Keywords: risk of bankruptcy, methods, rates

JEL Classification: E27, G17, M21.

Introduction

Risk is a always present element in the evolution of business. But how do we define risk? Risk can be defined as the threat that an event or action adversely affect an organization's ability to achieve its objectives.

Risk management standard developed by the Romanian Ministry of Public Finance[9] defines risk as being a problem (situation, event, etc.) not yet appeared, but which may occur in the future, in which case the results obtained previously fixed are threatened.

The economic crisis has led to deteriorating business environment, causing significant changes on all company's activities. We can said that regardless of the type of organization, it faces various risks: risks of organization (no procedures, lack of clear responsibilities), operational risks ( investment in an politically unstable country, investment in an sector with decreased demands, failure to register in the accounting records, lack of archiving ), financial risks (financing of activities which determines the level of indebtedness, unsecured payments, undetected operations with financial risk) and risk arising from legislative, structural or managerial changes. The risk sources are coming from both inside and outside an organization.

The internal sources are the result of events inside the organization. Usually, these risks are related to the technological process, how to use the equipment, as well as risks related to human resources, which are controlled by the organization. External sources are those sources 1. Classical bankruptcy risk models.

In bankruptcy risk analysis were used, over time, various methods: analysis of bankruptcy risk balance sheet patrimonial, rates method analysis, regression analysis, discriminant analysis. This latter method was initially used in the '30s in of risk as a result of events outside the organization that cannot be controlled. The concept of risk is closely related to the company's financial strategy and is linked to the cost of equity and borrowed capital and can be evaluated by the operating risk and the financial risk. The operating risk refers to the variation of the operating results achieved against the turnover. The financial risk is related with the net profit, considering the financial structure of the company 's capital (equity, longterm debt). If the company has no financial liability, financial risk is null. Long-term financial liabilities lead to a decrease in profits, and thus an increased financial risk. These risks may be limited or minimized by appropriate financial decisions or ensuring an optimal financial equilibrium. One of the greatest threats of an organization is bankruptcy and bankruptcy risk can occur due to internal or external causes. The bankruptcy risk is uncertainty due to the company capacity to face all the payments. The risk is an indicator that any potential investor take into account before investing. This is why, over time, the risk of bankruptcy was reviewed by researchers and practitioners and ample presented in the economic literature. If bankruptcy is not forecasted, investors and creditors will lose. According to [8], the investors lose approximately $41 \%$ of invested capital in listed companies failing within 4 days, while for unlisted companies, the value of a company may even fall by $80 \%$. Banks may have lost $69-72 \%$ of loans granted to firms in bankruptcy.

biology and natural sciences, later successfully being applied in academia and economy [1].. Using this last technique, a "Z" score for each analyzed company is obtained, showing whether the firm will be bankrupt. To determine the score the steps to be followed are: 


\section{"Mircea cel Batran" Naval Academy Scientific Bulletin, Volume XX - 2017 - Issue 1 The journal is indexed in: PROQUEST / DOAJ / Crossref / EBSCOhost / INDEX COPERNICUS / DRJI / OAJI I JOURNAL INDEX / I2OR / SCIENCE LIBRARY INDEX / Google Scholar / Academic Keys/ ROAD Open Access I Academic Resources / Scientific Indexing Services / SCIPIO / JIFACTOR}

- Selection of financial indicators that fairly reflect the company situation

- Selected indicators are compared between two firms in the same field, one of them in difficulty or bankrupt and the other without financial problem

- The selection of indicators that performs an discriminant action

- Z score values are determined and choose a value inflection (cut off value) for interpretation the score function that reflects the risk of bankruptcy.

"Z" score is calculated thus[2,3]: $Z=v 1 \times 1+v 2 \times 2$ $+\ldots \ldots \ldots . .+\operatorname{vnxn}(1)$ where $\mathrm{V} 1, \mathrm{~V} 2 . . . \mathrm{Vn}$ are discriminating factors, and $\mathrm{X} 1, \mathrm{X} 2, . . \mathrm{Xn}$ are independent variables.

The pioneer of studies on the risk of bankruptcy was Beaver, who in 1966, after a study on a sample of bankrupt companies with a good financial situation, has used 14 variables in the development of the model for forecasting bankruptcy risk, based on 5 financial ratios[6]. In 1968 Edward I. Altman, finance Professor at New York University has developed the Z score for predicting the risk of bankruptcy, based on analysis of 66 industrial enterprises during 19461965. The undertakings were divided into two groups (non-bankrupt /bankruptcy), being analyzed in terms of 22 indicators. The Model with 5 ratios, applicable only to listed companies was limited to enterprises whose total assets fell within 1- 25 million $\$$.

The Formula was[2]:

$Z=1.2 \times 1+1.4 \times 2+3.3 \times 3+0.6 \times 4+1.0 \times 5$ where

$\mathrm{X} 1$ = working capital/total assets,

$\mathrm{X} 2$ = retained earnings/total assets,

X3 = earnings before interest and taxes/total assets,

X4 = market value equity/book value of total liabilities,

X5 = sales/total assets,

Interpretation of the values obtained were as follows:

$$
\text { Z> 2,675 - safe area, no possibility of }
$$
bankruptcy

$1.81<Z<2675$ Grey Zone, minor risk of bankruptcy

$Z<1.81$ - Area stress, high risk of bankruptcy. Later, Altman[4] develop a model applicable to unlisted private companies, replacing in $\mathrm{r} 4$ the market value of equity with book value of equity, leading to the change in value coefficients, the new structure of the model is

$Z^{\prime}=0,717 r 1+0,847 r 2+3,107 r 3+0,420 r 4+$ 0,998 r5 where

$\mathrm{r} 1$ = (Current Assets - Current Liabilities) / Total Assets

r2 = Retained Earnings $/$ Total Assets

r3 = Earnings Before Interest and Taxes / Total Assets

r4 = Book Value of Equity / Total Liabilities

r5 = Sales / Total Assets, Interpretation of the results is as follows:

Z> 2.6 - safe area, low risk of bankruptcy

$1.1<Z<2.6$ - Grey Area, medium risk

$Z<1.1$ Zone stress, high risk of bankruptcy.

The Conan - Holder model applies to industrial enterprises with up to 500 employees. The model was built on a sample of 195 small and medium enterprises, half of which went bankrupt during 1970-1975. The authors determined a score applicable for industrial enterprises, construction enterprises, trade and transport enterprises. Of the 31 indicators used, Conan and Holder have detained five indicators that have used in the model below

$Z=0,24 \times 1+0,22 \times 2+0,16 \times 3-0,87 \times 4-0,1 \times 5$

Where

$\mathrm{x} 1$ - the operating profit / total debt;

$\mathrm{x} 2$ - permanent capital / total assets

x3 - claims + cash / total assets OR current assets / current liabilities

x4 - financial expenses / turnover;

X5 - personnel expenses/ added value.

Depending on the final score the likelihood of bankruptcy risk is determined:

\begin{tabular}{|l|l|l|}
\hline Score & $\begin{array}{l}\text { Bankruptcy } \\
\text { risk probability }\end{array}$ & $\begin{array}{l}\text { The situation } \\
\text { of } \\
\text { company }\end{array}$ \\
\hline$Z>0,16$ & below $10 \%$ & Very good \\
\hline $0,1<Z<0,16$ & $10-30 \%$ & Good \\
\hline $0,04<Z<0,1$ & $30-65 \%$ & Alert \\
\hline$-0,05<Z<0,04$ & $65-90 \%$ & Danger \\
\hline$Z<-0,05$ & over $90 \%$ & Bankruptcy \\
\hline
\end{tabular}




\section{"Mircea cel Batran" Naval Academy Scientific Bulletin, Volume XX - 2017 - Issue 1 The journal is indexed in: PROQUEST / DOAJ / Crossref / EBSCOhost / INDEX COPERNICUS / DRJI / OAJI I JOURNAL INDEX I I2OR / SCIENCE LIBRARY INDEX / Google Scholar / Academic Keys/ ROAD Open Access I Academic Resources / Scientific Indexing Services / SCIPIO / JIFACTOR}

When the z-score decreases and becomes negative, the risk of bankruptcy increases.

\begin{tabular}{|l|l|}
\hline Score & $\begin{array}{l}\text { Bankruptcy } \\
\text { probability }\end{array}$ \\
\hline 0,16 & $10 \%$ \\
\hline 0,13 & $20 \%$ \\
\hline 0,11 & $30 \%$ \\
\hline 0,09 & $40 \%$ \\
\hline 0,07 & $50 \%$ \\
\hline 0,05 & $60 \%$ \\
\hline 0,03 & $70 \%$ \\
\hline 0,002 & $80 \%$ \\
\hline$-0,05$ & $90 \%$ \\
\hline$-0,21$ & $100 \%$ \\
\hline
\end{tabular}

Users of the 2 models have assumed the risk that the models are not $100 \%$ accurate, because the models were created for companies that evolves into a stable economic environment and their use in other economies can lead to conflicting results. Beaver (1966) and Altman (1968) had numerous successors who developed the bankruptcy risk models .As [5] stated, two current (schools) appeared; the Anglo-Saxon School adopted the Beaver model, Altman models, Edmister model(1972) Diamond model(1976) Deakin model(1977) I Spring mode(1978), the Ohlson model(1982), the $K$ \& $P$ model [7] and the mainland school, represented by Yves Collongues (1976) Conan- Holder (1979), model of the Central Bank of France, French model Credit Commercial (CCF), Approved Accountants model (CA Score, 1987) or function score AFDCC 2 (1999).

In France, a Z score function is determined by the Central Balances Bank of France, composed of eight variables, as follows: $Z=-1,255 \times 1+$ $2,003 \times 2-0,824 \times 3+5,221 \times 4-0,689 \times 5-$ $1,164 \times 6+0,706 \times 7+1,408 \times 8-85,544$ Where X1 - operating profit / total liabilities - indicates own capacity for debt financing;

X2 - equity / total liabilities - indicates patrimonial solvency;

X3 - deposits and investments / total assets quantifies the performance of the assets;

X4 - financial expenses / turnover - indicates the level of financial charges

X5 - staff cost / value added - a measure of the degree of remuneration of staff;

X6 - equity / total assets;

X7 - Gross operating result / total assets;

X8 - the necessary working capital / turnover.
A function value $Z<-0.25$ indicates that the company has difficulties. If $Z$ is in the range of $0.25<Z<0.125$ indicates that the company is in a zone of uncertainty and if $Z>0,125$ enterprise has a favorable evolution.

2. Romanian models of bankruptcy risk.

Starting from the classical models of forecasting bankruptcy risk, economists belonging to the Romanian academics and the business environment have created models adapted to Romanian economy. Romanian bankruptcy model is a challenge given the economic context in which Romanian companies evolved since 1990, the economical characteristics of each sector and, not least, taking into account that models cannot be applied entirely to Romanian enterprises.

Currently, there are known several models for predicting bankruptcy, such as Anghel model, Robu - Mironiuc model, Cămăşoiu-Negoescu model, Mânecuță - Nicolae model, the BBăileşteanu model, I - Ivoniciu model , Statev model, but also models developed by banks (BCR model, Raiffeissen Bank model, BRD model). Anghel Model is based on a standard function based on standard function composed of four values, using indicators such as: net profit, total income, debts, total assets, cash flow. The standard function is calculated according to the model: $Z=5,676+6,3718 R 1+5,3932 R 2$ 5,1427R3 - 0,0105R4,

where R1 = net profit $/$ total income

$\mathrm{R} 2$ = debts / cash

R3 = debts / total assets

$\mathrm{R} 4$ = debts / total income The evaluation of a company's sustainability is based on the following classification (Breakdown / Bankruptcy) 0.0> z> 2.05 (favourable situation) 


\begin{abstract}
"Mircea cel Batran" Naval Academy Scientific Bulletin, Volume XX - 2017 - Issue 1
The journal is indexed in: PROQUEST / DOAJ / Crossref / EBSCOhost / INDEX COPERNICUS I DRJI / OAJI I

JOURNAL INDEX / I2OR / SCIENCE LIBRARY INDEX / Google Scholar / Academic Keys/ ROAD Open Access I Academic Resources / Scientific Indexing Services / SCIPIO I JIFACTOR
\end{abstract}

Robu - Mironiuc Model was elaborated on the study of a sample of 60 industrial enterprises, of different sectors that are quoted on the Stock Exchange Bucharest. The score function that determines the bankruptcy risk is presented as follows:

$\mathrm{Z}=-0,002 \mathrm{R} 1-0,028 \mathrm{R} 2-0,0570 \mathrm{R} 3+1,034 \mathrm{R} 4+$ $4,629 R 5+0,096 R 6+0,170 R 7-0,106 R 8$ $0,024 R 9+0,524$ where

R1= Circulating assets /Current debts

R2= Total assets/Current debts

R3= Total debts/Total liabilities

R4= Gross profit/Equity

R5= Net profit/Total

R6= Operating gross surplus/Turnover

R7= Total debts/Equity

R8= Financial expenses/Turnover

R9=Turnover/Stocks

The bankruptcy risk is determined by means of the following values:

- $1 \leq z<4$ the bankruptcy risk is low ;

- $0 \leq z<1$ the bankruptcy risk is average;

- $-4<z<0$ the bankruptcy risk is very high. Cămăşoiu - Negoescu Model is based on the economic analysis of the impact of more factors on the firm's relevant indicators, and is calculated according to a score function: $Z=[(3 R 1+6 R 2+4 R 3+3 R 4+6 R 5+3 R 6+3 R 7+5 R 8+5$ R9+5R10) / 4300]

where $\mathrm{R} 1=1 / \mathrm{Vi}=[(\mathrm{n} / \Sigma \mathrm{Vi}) \mathrm{X} 100] \mathrm{Vi}-$ the age of the management team members $\mathrm{n}$ - the number of the management team members

$\mathrm{R} 2=[($ receivables - debts / turnover $)] \times 100$;

$\mathrm{R} 3=$ (net profit / total costs) $\times 100$;

R4 = (equity / total assets) $\times 100$;

$\mathrm{R} 5$ = (short term patrimonial assets / patrimonial liabilities) $\times 100$;

$\mathrm{R} 6=$ (wages fund / total costs) $\times 100$;

$\mathrm{R} 7$ = (interests / amortization) $\times 100$;

$\mathrm{R} 8=$ (training expenses $/$ costs) $\times 100$;

$\mathrm{R} 9=$ (advertising expenses / costs) $\times 100$;
R10 = (employees in agencies / total number of employees) $\times 100$. By calculating the standard function, the following values and conclusions are obtained:

- $Z>180 \%$, the society obtains profit;

- $Z$ has a value included in the interval [50\%$180 \%]$, the company has problems and, if it applies for a loan, it has to be monitored;

- $Z<50 \%$, the company has serious problems and cannot get a loan.

3.Study case - Bankruptcy risk in OMV Petrom SA.

OMV Petrom is the largest integrated oil and gas group in Southeastern Europe, with an annual production of oil and gas of approximately 65 million boe in 2015. The group has a refining capacity of 4.5 million tons per year and operates a high efficiency power plant of $860 \mathrm{MW}$ and a 45 MW wind park. On the distribution market of oil products, Petrom is present in the markets of Romania and neighboring countries through 800 stations at the end of 2015. OMV, one of the largest listed industrial companies in Austria, holds a 51.01\% stake in OMV Petrom, the Romanian state through the Ministry of Energy holds 20.64\%, Fondul Proprietatea holds 18.99\% and $9.36 \%$ is free float on Bucharest Stock Exchange.Since 2008 the company has conducted an extensive restructuring and development process, which led to increased production and distribution capacity, while improving financial results. For the analysis of bankruptcy risk at OMV Petrom, I choose the reference years -2008, 2009 and 2012, and I analyzed the company's financial statements during these years[10]. The models used to determine the risk of bankruptcy was Altman model 2, Conan and Holder model, Anghel model.From data in Table no.1, I calculated the score using the Altman 2 model for three years as follows:

Table 1 - the $\mathrm{Z}$ score - model Altman 2

\begin{tabular}{|l|l|l|l|}
\hline Indicator & 2008 & 2009 & 2012 \\
\hline (Current Assets - Current Liabilities) & 5121 & 4470 & 5368 \\
\hline Total Assets & 24927 & 26713 & 38145 \\
\hline Retained Earnings & 6759 & 4219 & 4930 \\
\hline Earnings Before Interest and Taxes & 1129 & 1169 & 4583 \\
\hline Book Value of Equity & 13569 & 14056 & 23405 \\
\hline Total Liabilities & 11403 & 12657 & 14740 \\
\hline Sales & 16751 & 12842 & 19123 \\
\hline r1 & 0,205 & 0,167 & 0,140 \\
\hline r2 & 0,271 & 0,158 & 0,129 \\
\hline r3 & 0,045 & 0,043 & 0,120 \\
\hline
\end{tabular}


"Mircea cel Batran" Naval Academy Scientific Bulletin, Volume XX - 2017 - Issue 1 The journal is indexed in: PROQUEST / DOAJ / Crossref / EBSCOhost / INDEX COPERNICUS I DRJI / OAJI I JOURNAL INDEX I I2OR / SCIENCE LIBRARY INDEX / Google Scholar / Academic Keys/ ROAD Open Access I Academic Resources / Scientific Indexing Services / SCIPIO / JIFACTOR

\begin{tabular}{|l|l|l|l|}
\hline r4 & 1,189 & 1,110 & 1,587 \\
\hline r5 & 0,672 & 0,480 & 0,501 \\
\hline
\end{tabular}

Source: own calculations based on financial reports of OMV PETROM 2008-2012 Starting from the model $Z^{\prime}=0,717 \mathrm{r} 1+0,847 \mathrm{r} 2+$ 3,107 r3 + 0,420 r4 +0,998 r5 the folowing scores were calculated:

$Z^{\prime} \quad 2008=0,147+0,229+0,140+0,5+0,67=$ 1,686

$Z^{\prime} 2009=0,120+0,141+0,133+0,466+0,479$ $=1,339$

$Z^{\prime} 2012=0,1+0,109+0,373+0,667+0,5=$ 1,749 .

All scores are in the gray zone, with a low risk of bankruptcy. It can be concluded that the company was not in danger of bankruptcy before or after the economic crisis.

Although Conan Holder is specific model for companies under 500 employees, I have used this model to make a comparison on bankruptcy risk with Altman 2 model.Starting from the data in Table 2 the following scores related to Conan Holder are revealed

Table 2 - the Z score - Conan Holder model

\begin{tabular}{|l|l|l|l|}
\hline Indicator & 2008 & 2009 & 2012 \\
\hline EBE = gross surplus of exploitation & 1606 & 1698 & 3970 \\
\hline Total debts & 4950 & 6383 & 6860 \\
\hline Own capital & 12030 & 11229 & 22911 \\
\hline Total liabilities & 21353 & 23066 & 31461 \\
\hline Current assets - stocks & 2690 & 2316 & 3350 \\
\hline Financial expenses & 1635 & 619 & 658 \\
\hline turnover & 16751 & 12842 & 19123 \\
\hline Personnel costs & 2329 & 2344 & 1956 \\
\hline Added value & 10819 & 8936 & 14627 \\
\hline X1 & 0,324 & 0,266 & 0,578 \\
\hline X2 & 0,563 & 0,486 & 0,728 \\
\hline X3 & 0,125 & 0,1 & 0,106 \\
\hline X4 & 0,097 & 0,048 & 0,034 \\
\hline X5 & 0,215 & 0,262 & 0,133 \\
\hline
\end{tabular}

Source: own calculations based on financial reports of OMV PETROM 2008-2012

Starting from the $Z=0,24 \times 1+0,22 \times 2+0,16 \times 3-$ $0,87 \times 4-0,1 \times 5$ the yearly scores are:

Z $2008=0,077+0,124+0,02-0,084-0,0215=$ 0,1155

Z $2009=0,064+0,107+0,016-0,041-0,0133$ $=0,1327$

Z $2012=0,138+0,16+0,017-0,03-0,0133=0,2717$

In 2008 the risk of bankruptcy, calculated on Conan Holder model was $30 \%$, decreasing to $20 \%$ in 2009. After passing the economic crisis in 2012, the company recorded a bankruptcy risk below $10 \mathrm{pp}$.

Table 3 - the Z score - Anghel model

\begin{tabular}{|l|l|l|l|}
\hline Indicator & 2008 & 2009 & 2012 \\
\hline Net profit & 1002 & 1368 & 3850 \\
\hline Total incomes & 19331 & 14325 & 20962 \\
\hline Debts & 11358 & 12657 & 14499 \\
\hline Cash & 261 & 280 & 83 \\
\hline Total assets & 24927 & 27543 & 37411 \\
\hline R1 & 0,051 & 0,095 & 0,184 \\
\hline R2 & 43,51 & 45,2 & 174,69 \\
\hline
\end{tabular}

DOI: 10.21279/1454-864X-17-I1-022

130

(c) 2017. This work is licensed under the Creative Commons Attribution-Noncommercial-Share Alike 4.0 License.
Among Romanian models, I choose Anghel model $Z=Z=5,676+6,3718 R 1+5,3932 R 2-$ $5,1427 R 3-0,0105 R 4$, to compare the results with those of classic models.

Based on data extracted from the financial statements of OMV Petrom during 2008 - 2012 (see table 3) we calculated the scores related to the 3 years:

Z $2008=5,676+0,324+234,65-2,34-0,006=$ 238,304

Z $2009=5,676+0,605+243,77-2,36-0,009=$ 247,682

Z $2012=5,676+1,172+942,14-2,00-0,07=$ 946,918 
"Mircea cel Batran" Naval Academy Scientific Bulletin, Volume XX - 2017 - Issue 1 The journal is indexed in: PROQUEST / DOAJ / Crossref / EBSCOhost / INDEX COPERNICUS I DRJI / OAJI I JOURNAL INDEX I I2OR / SCIENCE LIBRARY INDEX / Google Scholar / Academic Keys/ ROAD Open Access I Academic Resources / Scientific Indexing Services / SCIPIO / JIFACTOR

\begin{tabular}{|l|l|l|l|}
\hline R3 & 0,455 & 0,459 & 0,387 \\
\hline R4 & 0,587 & 0,883 & 0,691 \\
\hline
\end{tabular}

Source: own calculations based on financial reports of OMV PETROM 2008-2012 [10]

In accordance with $Z$ value, $Z>2,05$ we can say

that during $2008-2012$ there was no risk of

bankruptcy in OMV Petrom.

\section{Conclusions}

Bankruptcy risk models have a statistical character, being constructed for stable economies and fields with specific characteristics. The models used in this analysis have several common elements: using five variables, can be applied the industry sector which includes OMV Petrom and are based on the company's financial results over a long period of time. The results

score obtained converge to the same conclusion: the company faces the economic crisis, recorded financial results that have enabled sustainable development in all business segments (Upstream, Downstream Oil, Downstream Gas), the risk of bankruptcy of the company is virtually nonexistent.

\section{Bibliography}

[1]. Altman, E., R. Avery, R. Eisenbeis and J. Sinkey, 1981, Applications of Discriminant Analysis in Business, Banking \& Finance, JAI Press, Greenwich, CT.

[2]. Altman E, Financial Ratios, Discriminant Analysis and the Prediction of Corporate Bankruptcy, Blackwell Publishing, American Finance Association, Journal of Finance, Vol.23, No.4, September 1968, pp.589-609.

[3]. Altman E, Revisiting Credit Scoring Models in a Basel II Environment, Credit Risk, Credit Rating: Methodologies, Rationale and Default Risk, Ong M. Ed London Risk Books, 2002, pp.7-19, https://pdfs.semanticscholar.org/9899/c671599ca41a1310d9b5e0ed5a3953c930f0.pdf

[4]. Altman E.I., Corporate Financial Distress. A Complete Guide to Predicting, Avoiding, and Dealing with Bankruptcy, Wiley Interscience, John Wiley and Sons, 1983; also see E. Altman \& E. Hotchkiss, Corporate Financial Distress \& Bankruptcy , 3rd edition, John Wiley, 2006.

[5]. Anghel, I., Falimentul. Radiografie şi predicţie, Editura Economica, București, 2002

[6]. Beaver, W., 1966, "Financial Ratios as Predictors of Failures," in Empirical Research in Accounting, selected studies, nr.4, pp. 71-111.

[7]. Clark, C. E., Foster, P. L., Hogan, K. M., Wehster, G. H. (1997 Summer). Judgemental approach to forecasting bankruptcy. Journal of Business Forecasting, Vol. 16, issue 2, p. 14-18

[8]. Robu Vasile, Anghel Ion, Șerban Elena Claudia, Analiza economico-financiară a firmei, Editura Economică, București, 2014, pag. 501

[9]. www.mfinante.ro, http://static.anaf.ro/static/10/Anaf/legislatie/OMFP 946 2005.pdf

[10]. http://www.omvpetrom.com/portal/01/petromcom/petromcom/OMV Petrom/Annual Report 